\title{
Effect of Forensic Accounting and Litigation Support on Fraud Detection of Banks in Nigeria
}

\author{
Bassey, Bassey Eyo, Ahonkhai, Ohimai Ebahi \\ Department of Accounting, Faculty of Management Sciences, \\ University of Calabar, P.M.B. 1115, Calabar, Cross River State-Nigeria,
}

\begin{abstract}
The study critically considers the effect of forensic accounting and litigation support on fraud detection in Nigerian companies. The objective of this study is to predispose if forensic accounting and litigation support have any significant effect on fraud detection in Nigeria companies. In order to actualize this objective, data were sourced for through primary sources and this was achieved with the help organized questionnaires of two segments administered to the employees of Zenith Bank Nigeria Plc. and Union Bank Nigeria Plc. in Calabar, Cross River State. The data collected were presented with the help of tables and interpreted with the help of inferential statistics using Analysis of Variance (ANOVA). The study revealed that forensic accounting and litigation supports do not have significant effect on fraud detection in Nigerian companies. It was recommended that Management and Shareholders should be educated on the usefulness of the services of forensic accountants in litigation matters and that Nigeria legal system should be strengthened, so that it can lend credibility or confidence in their legal system.
\end{abstract}

Key words: Forensic Accounting, Corruption, Litigation Support, Fraud, Fraud Detection

\section{Introduction}

The emerging issues of falsification of financial statement in the $21^{\text {st }}$ century, that has dominated the headlines for years now, most especially the case of Enron and WorldCom has made people to ask if auditors actually exist or if auditors really play any vital role towards the accountability and avoidance or detection of fraud. These emerging issues have made the term forensic accounting very popular.

Forensic accounting is not a new aspect of accounting as it is believed to be, it has been in existence for a very long time. As at 1554 a man by the name Hercules De Cordes, a school teacher and bookkeeper, testified on 3 occasions as an expert witness, by the late 1800s articles about fraud investigations and expert witnessing began to appear (Crumbley, Heitgerb \& Smith, 2009). The person credited to likely being the first to use the phrase forensic accounting was Maurice E. Peloubet, a partner in the public accounting firm Pogson, Peloubet and company in New York. (Golden, Skalat \& Clayton, 2011).

Hopwood, Leiner \& Young (2011) defined the word forensic accounting as

The application of investigative and analytical skills for the purpose of resolving financial issues in a manner that meets standards required by courts of law, Forensic accountants apply special skills in accounting, auditing, finance, quantitative methods, certain areas of the law, research and investigative skills to collect, analyze and evaluate evidential matter and to interpret and communicate findings.

However, fraud happens to be the most popular aspect that forensic accounting is being applied, but there are many other areas in which forensic accounting can be applied to e.g.

- Laws, court and Dispute Resolution

- Business valuation

- Economic damages calculation

- Bankruptcy, insolvency and restructuring of an organization

- Family law

- Financial statement falsification e.t.c.

(Crumbley et al., 2009)

Forensic accounting is therefore that aspect in accounting that deals with legal review and presentation of the greatest height of Assurance.

It is very important to note that in Nigeria there a drastic growth in the perpetration of fraudulent activities in companies which has led to a great need in the perceptibility of forensic accountants.

\subsection{Statement of problem}

Ojaide (2000) summits that there is an increase in the number of fraud and fraudulent practices in Nigeria emphasizing the visibility of forensic accounting services. Okoye and Akamobi (2009), Owojori and Asaolu (2009), Izedonmi and Mgbame (2011), have all acknowledged in their work that there is a rapid growth in the occurrence of fraud and fraudulent practices in Nigeria. As Kasum (2009) notes, the continuance of 
corruption and financial fraud has become an area of specialization in both the public and private sectors as people now carry out corrupt and fraudulent activities in accordance to the ability of their position in the firm. It is a perception that forensic accounting will be able to curb financial wrongdoings present in most Nigeria companies.

However stakeholders have been talking about corruption and fraudulent practices in Nigerian companies, but then is there any consciousness among these people to charge perpetrators of fraud to court and use forensic accounting and litigation support. Has there been any case of fraud in Nigeria whereby the perpetrators where charged to court and forensic accountants where called to testify (based on the facts they have established) as expert witness. This work seeks to investigate cases of fraud in the Nigerian banking sector that have occurred and were charged to court as well as to see if forensic accounting techniques were applied to these cases.

\subsection{Forensic accounting theory}

\section{Literature Review}

Forensic accounting is an amalgamation or blend of accounting principles and investigative techniques in gathering financial information that would act as evidence and will be acceptable in the court of law. A forensic accountant must be knowledgeable in some areas which includes

1. A good knowledge of the preparation, presentation and interpretation of financial statements.

2. A good understanding of the concept of fraud and its schemes.

3. Ability to understand the internal control system of the company.

4. Good knowledge on information technology.

5. Good knowledge on psychology which will help to understand the behaviour of the people around.

6. Good communication skill.

7. Knowledge of criminal and civil law.

(Anizoba, Ezugwu \& Obumse, 2005).

In order for a forensic accountant to easily carry out his job, there are certain approaches to be adopted. They include:

1. Prediction

This is the circumstance that leads a professional to know and believe that fraud has taken place.

2. Fraud investigation plan

This is as a result of the forensic accountant's knowledge and the interpretation of fraud schemes.

3. Analysis of records and evidence gathering

The books of accounts are checked in order to obtain adequate data that will be relevant and reliable to act as evidence that will be used by the forensic accountant.

4. Interview process

A forensic accountant has to have a one on one interaction with witnesses in other to gather data/information that could be useful in litigation support.

5. Report writing

This is the putting together of the data/information gathered in a report form, and this report will be given to those that hired him. If in the process the case was charged to court, the report would serve as evidence and support for prosecution the perpetrator of the fraud.

(Singleton, Singleton, Bologna \& Lindguist, 2006)

\subsection{Fraud theory}

Fraud is any illicit act distinguished by deceit, concealment, or breach of trust. These acts are not clinging upon the pertinence to obtain money, property or services; to avoid payment or loss of services; or to secure personal or business gratification. In the case of Wells v Zenz, fraud was defined as

A generic firm which embraces all the multifarious means which humans ingenuity can devise and are resorted to by one individual to get any advantage over another. It includes all surprise, trick, cunning, dissembling and unfair ways by which another is deceived.(Wells, 2006))

In the legal system fraud is referred to as the deliberate miscalculation of the truth to enable an individual to maneuver an organization. Fraud enables an individual to enrich himself deliberately by manipulating something secretly.

When companies face some serious financial challenges and end up winding up it is not usually because the company wasn't performing well but sometimes it is as a result of fraudulent activities that have been perpetrated by employees or management of the company.

There are 3 major types of fraud

1. Personal use of business resources:

This is the theft or misuse of assets or fund by an employee of a company 
2. Falsification of the financial statement:

This is the conscious misstatement or omission of material information in a company's financial statement e.g. by recording fictious revenue, concealing liabilities e.t.c. This would either lead to overstating profit (in order to make the company look very profitable to shareholders, other users of financial statement and prospective investors) or understating profit (in order to reduce the company's tax liability).

3. Corruption:

This is when an employee of an organization uses his or her office/influence in a way that violates his/her duty to the employer.

However from the perspective of Personal use of business resources, there are three major levels of fraud that exist. They include

1. Management level fraud e.g. Misappropriation of cash and asset. Falsification of financial statement, irrelevant purchases, lapping.

2. Employees level fraud e.g. petty cash, manipulation of expense account, stock theft.

3. External level fraud e.g. cheque forgery, substitution of product, false invoice, false representation.

Taking a glance at financial reporting situation, there are 3 major types of fraud that exist. They include

1. Manipulation and falsification of the books of account.

2. Misrepresentation or conscious omission from the financial statement.

3. Conscious misapplication of globally accepted accounting principles in the preparation of the financial statement.

(Crumbley et al., 2007)

\subsection{Detection of fraud}

In the past the need for detecting fraud was not as important as it is today. Fraudulent practices have increased greatly in today's corporate world. The detection of fraud starts with an indication that something is wrong somewhere. This might be as a result of the lifestyle of the employees or managers.

Company's fraud can be discovered in two major ways

1. Discovery by accident

2. By carrying out research and supporting identification of problems.

In the past many acts of fraud have been detected by accident. Most times employees who are opened to fraud are aware that fraud has taken place but could not expose it because they are not so sure of it, or they are not ready to point fingers at anyone or they do not know how to go about informing or reporting to the relevant authorities that fraud has been perpetrated because they are scared of being called whistleblowers.

However, fraud is very expensive. A lot of investors in the world have lost their monies invested in companies as a result as a result of presentation of falsified financial statement, asset misuse and corruption.

In order to regain public hope and reliability on auditors, those that are embedded with the responsibility of setting accounting standards have added the procedures auditors are supposed to follow in order to discover fraud but even at that it is not the outright duty of an auditor to discover fraud, it is the sole duty of a forensic accountant.

\subsection{Forensic accounting and detection of fraud}

Albrecht (2005) disagreed that fraud is not something that is identified often but that the signs are usually noticed. The sign does not necessarily mean that fraud has occurred or taken place because it may be an error. It is recommended for someone to be careful when informing relevant authorities about fraudulent activities because it may be a wrong accusation. It is quite difficult to establish facts about fraud because it is done in a very careful manner, so that it cannot or will not be easily discovered. Those perpetrating fraud are becoming wiser and more tactful by the day due to the attainable or likely errors individuals can instigate. This has made the discovery and justification of fraud a very difficult task for forensic accountants. It is imperative for forensic accountants to have a strong knowledge of the methods these fraudulent individuals adopt. Outside the consistent participation of people and the development and advancement of forensic accounting, fraudulent practices will be very difficult to discover therefore lead to a better or favorable outcome in financial deception and this transcribes the loss of trust of the shareholder, prospective investors and the public at large.

Accounting failure and poor corporate governance is part of what gave rise to fraudulent practices in Nigeria. A group of individuals with like mind or similar mindset will take advantage of poor corporate governance to perpetrate fraud in a firm. Another reason is the corporate reporting system and this is due to inadequate implementation or employment of policies and practices of the company and this will enable the company to accomplish their goals easily. The difficulty in company's today is that management does not develop the right attitude towards adopting policies. Another problem is the liability of management to state the truth and be transparent in the presentation of their financial statement. It is true that it is not the sole duty of an auditor to discover fraud, but the auditor should be able to be independent in his opinion and give a true and fair 
view on the financial statement in order to protect the interest of the employees and also the public. When forensic accounting guidelines are adhered to, auditors can act in the capacity of forensic accountants in case of criminal activities in a company. Ineffective internal control system in a company shows that the management system is weak and inefficient and cannot implement certain decisions. Companies should look for new approach to curb fraudulent practices and forensic accounting is the best method or approach to adopt.

\subsection{Litigation support}

Litigation support takes into cognizance the interpretation and representation of problems that are connected to helping current or imminent litigation. In this aspect of knowledge the forensic accountant might be told to attach a supposed value for the loss caused by those involved in the legal conflict and also asked to help in providing solution to conflicts even before they go to court. Due to the knowledge of forensic accountants they are usually intended to be proficient consultants and expert witness.

\section{Methodology}

This study aimed at providing answers as to if forensic accounting and litigation support have any significant effect on fraud detection in Nigerian companies. However, there are 15 banks in Nigeria, all of these banks have branches in Calabar. Zenith bank is one of the fastest growing banks in terms of its shareholders earnings, market capitalization and value of its shares, banks network, among other indices. On the other hand, union bank plc had problems about 3 years ago as a result of fraud and mismanagement to the extent that workers were retrenched, the Managing director retired among other corporate governance failure issues. Therefore, it was necessary to conduct a survey research using these two banks for the study. Data were collected from a sample of 60 respondents from a population of 120 staff of these banks through a systematic sampling technique using an interval scale of 2. The respondents were made up of senior and middle level staff of these banks. The questionnaire instrument was developed and validated. It was a 5-point likert scale structured questionnaires which respondents were expected to express their views on the basis of the answers provided by the researchers. Analysis of variance (ANOVA) statistical technique was applied to analyze the responses. The ANOVA was considered to be a suitable statistical technique since it measures and establishes whether the differences in mean samples result occurs by chance or are a result of the treatment on each of the samples.

\section{Findings/Results}

The study reveals that fraud has become a norm in Nigerian companies and this agrees with the work of Ojaide (2000), Okoye and Akamobi (2009), Izedonmi and Mgbame (2011). The study however shows that forensic accounting and litigation support does not have significant effect on fraud detection and this could be due to the fact that most of the fraud cases in Nigerian companies don't end up in court. Once fraud is discovered at the first phase no further forensic accounting technique is applied to establish facts that would be used as evidence in the court of law. Most companies and perpetrators of fraud in Nigeria prefer to settle out of court.

\section{Conclusion/Recommendations}

In summary the study found out that fraudulent practice in Nigerian companies is real and is spreading very fast. This problem of fraud has to be dealt with before it gets out of hand. Forensic accounting is that branch of accounting that aims to detect and deal with fraudulent practices within and outside a company and this is achieved by the application of a set of investigative techniques. The study found out that forensic accounting and litigation does not have significant effect on fraud detection. However forensic accounting is growing rapidly globally and the $21^{\text {st }}$ century accountants must utilize its accounting, auditing and investigative skills in other to restore confidence in Nigerian companies. After a critical consideration of the findings of this study, the following recommendations are suggested.

1. Management and shareholders should be educated on the usefulness of the services of forensic accountants in litigation matters.

2. Nigeria legal system should be strengthened to lend credibility or confidence in their legal system. This will encourage people to go to court.

\section{Reference}

[1]. Abuchi, E.O. (2013). Understanding forensic accounting from financial/economic crime perspective. The Certified National Accountant, 21(4), 36-38.

[2]. Albrecht, S., Albrecht, W. \& Albrecht, C.C. (2006).Fraud examination. (2nded.). Mason: Thomson South-Western.

[3]. Anizoba, E.N., Ezugwu, D.C. \& Obumse, A.A. (2005).Forensic Accounting issues and options, M.Sc. seminar paper, Department of Accountancy, Nnamdi Azikiwe University, Akwa.

[4]. Crumbley, D.L, Heitger, L.E \& Smith G.S. (2007). Forensic and investigative Accounting, ( ${ }^{\text {rd }}$ ed.). Chicago: CCH Incorporated. 
[5]. Crumbley, D.L, Heitger, L.E \& Smith G.S. (2009). Forensic and investigative Accounting, (4 ${ }^{\text {th }}$ ed.). Chicago: CCH Incorporated.

[6]. Golden, T.W., Skalak, S.L. \& Clayton, M.M. (2011). A guide to Forensic Accounting Investigation. (2 ${ }^{\text {nd }}$ ed.). Hoboken NJ: John Wiley and Sons.

[7]. Hopwood, W.S, Leiner J.J. \& Young, G.R. (2011). Forensic Accounting and Fraud Examination, (2 ${ }^{\text {nd }}$ ed.). New York: McGraw-Hill Irwin.

[8]. Izedonmi, F.I. \& Mgbame, C.O. (2011).Curbing financial frauds in Nigeria, a case for forensic accounting. African Journal of humanities and society, 1(12), 52-56.

[9]. Ojaide, F. (2000). Fraud detection and prevention: the case of pension accounts ICAN NEWS January/March.

[10]. Okoye, E.I. \& Akamobi, N.L. (2009). The role of forensic accounting in fraud investigations and litigation support. The Nigerian Academic Forum 17 (1).

[11]. Osisioma, B.C. (2013). Fraud prevention in Nigeria: Applying the forensic accounting tool. The Certified National Accountant, 21(4), 8-15.

[12]. Owojori, A.A. \& Asaolu T.O. (2009).The role of forensic accounting in solving the vexed problem of corporate world. European Journal of Scientific Research.29 (2), 183-187.

[13]. Singleton, T.W., Singleton, A.J., Bologna, G.J. \&Lindguist, R.J. (2006).Fraud Auditing and Forensic Accounting,(3 ${ }^{\text {rd }}$ ed.). New Jersey: John Wiley \& Sons.

[14]. Wells J.T. (2006). Corporate Fraud handbook: Prevention and detection. New Jersey: John Wiley and sons Inc.

[15]. Wells, J.T \& Zens, C. (2005).Principles of Fraud examination. Hoboken, NJ: Wiley. 